\title{
MINIMALLY INVASIVE ENDODONTICS AND PERMANENT RESTORATIONS OF ENDODONTICALLY TREATED TEETH: LITERATURE REVIEW
}

\author{
Mohammad I. Al-Obaida*
}

\begin{abstract}
The primary goal of endodontic therapy is the long-term survival of a functional tooth through the prevention and/or treatment of apical periodontitis. However, successful endodontic outcomes depend on many factors, such as the structural integrity of the tooth after root canal preparation and the quality of the final restoration. The field of endodontics is continuously changing due to the introduction of new techniques and technological advances. Currently, minimally invasive endodontics is considered as the recommended approach during root canal therapy, with permanent restorative decisions saved for the postoperative period. Various materials and techniques have been developed and/or proposed to increase the life span of endodontically treated teeth while maintaining adequate root strength and maintaining the balance between biological, mechanical, adhesive, functional, and esthetic parameters. This critical review aims to assess the literature on recent trends in conservative endodontic treatment and adhesive dentistry for the restoration of endodontically treated teeth.
\end{abstract}

\section{INTRODUCTION}

Survival of the tooth over extended periods of time is considered as a measure of success after endodontic treatment. Such success does not depend solely on endodontic treatment but also requires well-condensed obturation after the removal of necrotic and infected tissue to prevent further microbial proliferation into the canal system. ${ }^{1}$ Achieving an adequate coronal seal is key in preventing the ingress of microbes into the canal system. $^{2}$
Endodontically treated teeth often fracture under functional forces. This may be attributed to the excessive loss of tooth tissue after exposure to caries, physical trauma, abrasion, and erosion. ${ }^{3}$

Several studies have suggested that saving the natural tooth requires excellent endodontic treatment as well as follow-up for restorative treatment. Previous reports have shown that teeth that are not permanently restored after endodontic treatment are 2-4 times weaker than teeth that are permanently restored after endodontic treatment.

\footnotetext{
* Associate Professor / Consultant Endodontist, King Saud University, College of Dentistry
} 
Teeth that are not permanently restored may require extraction. $^{4-6}$ After endodontic treatment, the remaining tooth structure should be preserved carefully in terms of quality and integrity to provide a solid base for restoration and to increase the structural strength of the tooth. ${ }^{7-9}$ Current efforts to restore endodontically treated teeth aim to prevent extension by maximizing the preservation and conservation of enamel, dentin, and the dentinoenamel junction. ${ }^{10}$ This goal is currently achieved through the use of minimally invasive dentistry with the aid of magnification and electrical handpieces. Bonding is optimized through the use of immediate dentin sealing and proper forms of isolation. $^{11-13}$

The restoration of endodontically treated teeth is often considered to be distinct from root canal treatment. However, root canal treatment as well as restoration must be considered to plan and execute the strategy that will optimize treatment prognosis.

Because of the complexity involved, dentists restoring endodontically treated teeth must ensure that every phase of treatment is appropriate, wellexecuted, and timely. ${ }^{14-16}$

In recent years, the restorative approach to endodontically treated teeth has benefited from the availability of proven and reliable adhesive dental techniques, which have expanded the restorative options available to clinicians. Although the concept of minimally invasive dentistry for dealing with endodontically treated teeth is gaining popularity, clinicians continue to face challenges in selecting the ideal restorative material for coronal coverage. The dental community has not yet reached a consensus regarding the ability of conservative coronal coverage options such as endocrowns to effectively balance biological, mechanical, adhesive, functional, and esthetic considerations in the treatment of endodontically treated teeth.

\section{Trends towards conservative endodontic treatment}

\section{Minimally invasive endodontics}

The incidence of vertical root fracture in endodontically treated teeth may be related to the amount of dentin removed during endodontic treatment, which is considered to be a modifiable factor. ${ }^{17}$ The concept of minimally invasive endodontics should coexist with the biological and mechanical objectives of traditional access to the cavity, such as the ability to physically penetrate, funnel, and unroof the pulp chamber. ${ }^{18}$

\section{Conservative access}

There has recently been a shift towards reducing the amount of tooth structure removed during endodontic treatment. Instead of traditional access design, the focus is now more tailored to a specific tooth's location and the size of the access cavity.

Several modifications have improved upon traditional access cavity designs, such as the "Ninja" outline and constructed or conservative endodontic access cavities, as recommended by Clark and Khademi. ${ }^{19-21}$ Buchanan proposed "X-entry" access cavity design, which minimizes the removal of dental material from the critical tooth trunk..$^{22}$

\section{Maintaining pericervical dentin}

Maintaining the structural integrity of the pericervical area of the tooth (approximately $4 \mathrm{~mm}$ above and below the alveolar crest) is important, especially in the treatment of molars, which require pericervical dentin for long-term survival. In molars, pericervical dentin serves as the tooth "neck", increasing fracture resistance and enhancing the ferrule. ${ }^{18}$ The tooth soffit is a small piece of "roof" that surrounds the pulp chamber and behaves like the metal that holds together the wood panels of a barrel. The soffit must be maintained to avoid collateral damage such as lateral wall gouging. ${ }^{19,23,24}$ 


\section{Technological advancement}

The field of endodontics has adopted numerous advancements in technology and materials. The introduction of the microscope to endodontics in the early 1990s was followed by an increase in the availability of ever-more-flexible nickel-titanium rotary instruments. ${ }^{25}$

\section{Image-guided access}

Recently, image-guided access utilizing 2D projection radiography as well as $3 \mathrm{D}$ cone beam computed tomography (CBCT) are used to precisely design the access cavity and thus improve survival outcomes. ${ }^{26}$ One implementation of image-guided access design is "truss" access (i.e., dual access) which is the access design of choice in a mandibular molar with minimal canal convergence and a wide platform. ${ }^{26}$

\section{Dynamically guided access}

Dynamic guidance was introduced in the early 2000s to facilitate the accurate placement of dental implants. ${ }^{27}$ Dr. Charles Maupin used this approach to secure dynamically guided access during endodontic treatment. ${ }^{22}$ Static guides may be fabricated by 3D printing based on CBTC. Furthermore, intraoral scanner data can guide clinicians during endodontic access or microsurgery. ${ }^{28}$ Dynamically guided access provides the dentist with a significant advantage. This approach does not require the use of long burs and may be performed with high-speed handpiece burs. Dynamically guided access does not require the dentist to wait for the preparation of a 3D-printed guide and allows for changes to the treatment plan to be made in real time. ${ }^{22}$

In dynamically guided access, the clinician gets immediate feedback about the bur as it relates to the position of the previously planned path of access and the tooth by tracking it overhead with cameras in $3 \mathrm{D}$ space. The data obtained with these cameras is then transferred to the software interface..$^{22}$

\section{Conservative root canal instrumentation}

Root canals are complex anatomic systems that may be asymmetrical or oval in cross-section, with concavities and convexities on the canal walls as they branch, dilacerate, and/or divide. ${ }^{29}$ Traditional root canal instrumentation involves the use of a large coronal taper to enhance irrigation and disinfection and to provide a convenient from of resistance for obturation procedures. ${ }^{6}$ However, tooth survival is influenced by the distribution, amount, strength and integrity of the remaining tooth tissue. ${ }^{15}$ Original healthy tissue has the best biological value, and the current evolution in minimalistic approaches to access design focuses on tissue preservation, by shifting the outline configuration toward greater dentin preservation and prioritizing the endodonticrestorative interface. ${ }^{30}$

\section{Minimal taper design and small apical size}

Fortunately, technological advances in the instrumentation armamentarium have brought us closer to the aims of minimally invasive endodontics. We are in a new era in endodontics, with the introduction of improved disinfection systems that do not require changing the non-round canal to a round shape with aggressive canal flaring. ${ }^{31 ; 32}$

Nowadays, there is a shift in instrumentation technique, from enhanced apical instrumentation and larger apical diameters to smaller apical preparations and a continuous taper throughout the canal. A larger apical diameter is associated with minimal taper in the shape of the canal, which may weaken root structure. This type of preparation promotes resistance form, a tight apical seal, and a conservative approach to creating a shape sufficient for adequate disinfection as well as the preservation of root dentin. 33; 34; 35 Researchers have shown that bacteria can be eliminated just as easily from cavities with smaller apical size as from cavities with large apical size..$^{36 ; 37}$

Using super-elastic rotary and nickel-titanium instruments rather than traditional stainless steel 
may facilitate the treatment of a wide range of anatomical variations, resulting in preparations that are more effectively centered, requiring less straightening. ${ }^{38 ; 39}$

\section{Advancements in root canal irrigation}

The search for techniques to enhance irrigation efficacy has continued because current cleaning and shaping methods often fail to remove all bioburden from the root canal system. Recent studies have focused more on physical means that facilitate disinfection, such as sonic, ultrasonic, photo-induced photo-acoustic streaming, and laser activation. ${ }^{40 ; 41}$

The effectiveness of tissue dissolution has been reported to increase 8-fold with use of the GentleWave System (Sonendo, Inc., Laguna Hills, $\mathrm{CA})$, compared with the use of conventional irrigation systems, ultrasonic irrigation, and the EndoVac. ${ }^{42}$ When compared with the passive ultrasonic system and conventional needle irrigation, tissue dissolution with the GentleWave system removes more calcium hydroxide, even that found in the apical third of the tooth..$^{43}$ One in vivo clinical study reported that use of the GentleWave System for root canal treatment achieved successful healing in $97.4 \%$ of cases within 6 months of the initial treatment. The results of histological analysis showed that the GentleWave system removed $97.2 \%$ of tissue debris in the apical and middle thirds of the mesial roots of mandibular molars, including the isthmus. ${ }^{44}$

\section{Vital pulp therapy - 'Endolight'}

New biologically driven treatment protocols have been developed for the treatment of cases with irreversible pulpitis. Recent clinical research on vital pulp therapy has provided new insights into pulp biology. Simon et al. and Tomson et al. found that morphological changes indicating inflammation or necrosis occurred principally in the coronal pulp, while the radicular pulp remained viable. ${ }^{45 ;} 46 ; 47$ Research has shown that outcomes following vital pulp therapy are comparable to those seen after conventional root canal treatment. ${ }^{48}$ Moreover, with this approach, the biological immune response can improve treatment outcomes by preventing infection of the apical area. Experts advise others to retain radicular pulp tissue and to avoid full pulpectomies. This preservation of the pulp tissue maintains the tooth's physiological and defensive functions. Less hard tissue is removed, which results in stronger teeth. ${ }^{45}$ Vital pulp therapy simplifies treatment and decreases risk for treatment complications associated with difficult root canal anatomy, at reduced cost. Patients also report less postoperative pain, in comparison to those who underwent conventional root canal therapy. ${ }^{46}$ To ensure successful outcomes after vital pulp therapy, proper case selection and treatment protocols should be followed. ${ }^{49}$

\section{Bioceramics as sealers in endodontics}

Warm condensation multiphase (guttaperchasealer) techniques are currently common practice in the field of endodontics. However, this approach increases the risk for microleakage because of the lack of adhesion or chemical bonding between the dentin walls of the root canal and the materials used to fill it, the shrinking of guttapercha after the use of warm condensation is also an issue. The quest for endodontic sealers that adhesively and chemically bond to root canal walls therefore continues. ${ }^{50}$

The microspace issue associated with traditional sealers can be overcome through the use of bioceramic-based sealers. Such materials are hydrophilic and adhesive, bonding chemically to the dentin walls of the root canal. Due to their hydrophilic nature and the low contact angle, bioceramic sealers can spread easily over the dentin walls of the root canal to penetrate and fill lateral microcanals as well. Thus, the traditional approach to instrumentation in the canals with ( $\geq 06$ taper) is no longer needed. Moreover, tooth tissues are preserved and the risk for root fracture is reduced. ${ }^{51}$

Bioceramic sealers have been shown to improve the fracture resistance of endodontically treated 
teeth. In particular, iRoot SP (especially in combination with bioceramic-impregnated and -coated guttapercha cones) has been shown to increase the fracture resistance of endodontically treated roots. ${ }^{52}$ Fracture resistance was also increased when the product was used in simulated immature roots, ${ }^{53}$ and when used in mature roots with AH Plus, EndoSequence Sealer, and/or MTA Fillapex. ${ }^{54}$ Surface bonding to the sealer eliminates a critical pathway for the coronal leakage of microbes in the case of a defective seal during coronal restoration. ${ }^{55}$ Endodontic grafting utilizes the osseoconductive effects of cemented hard tissue to promote physiological closure of the root canal's apical orifice. ${ }^{56}$

\section{Structural changes in endodontically treated teeth}

Contrary to common belief, variations in biological tissue quality after endodontic treatment have only a negligible effect on the tooth's structural strength. Rather, structural strength is affected by the amount and integrity of hard tissue. The loss of tooth tissue during cavity access and other root canal preparations has a more deleterious effect on tooth strength than dehydration or physical changes in the dentin. ${ }^{57}$

The fabrication of a conservative access cavity has been found to minimally affect the fracture resistance of a tooth, compared with the loss of marginal ridges. ${ }^{58}$

One study investigated the effects of endodontic and restorative procedures on cusp durability in healthy human teeth. The results indicated that endodontic procedures, occlusal cavity preparations, loss of one marginal ridge, and loss of both marginal ridges cavity preparations reduced tooth strength by $5 \%, 20 \%$ and $63 \%$, respectively. ${ }^{18}$

\section{Current opinion on the restoration of endodonti- cally treated teeth}

Torabinejad and colleagues reported that the main advantage of coronal restoration after endodontic treatment is the prevention of root apex contamination. In endodontically treated teeth that do not receive coronal restoration, bacterial products tend to contaminate the root apices within 3 weeks. ${ }^{59}$ The clinical success of the coronal restoration of endodontically treated teeth depends on the degree of destruction present initially. ${ }^{60}$

Recent technological advancements in the field of dentistry have led to the development of alternative treatment options for cases involving non-vital teeth with substantial tissue loss. For example, partial indirect coronal coverage restorations and endocrowns have been introduced to replace traditional post-core restorations with full coronal coverage crowns. ${ }^{61}$

High-precision technological advancements, in combination with the advent of adhesive dentistry, reduce chair-side time and increase patient satisfaction with treatment outcomes. Dentists work today to minimize preparation of remaining tooth structure and to preserve radicular and pericervical dentin by eliminating the need for a post. ${ }^{62,63}$ The monoblock effect improves the distribution of masticatory stresses by eliminating the horizontal peak loads caused by the presence of a post within the root canal. ${ }^{64 ;} 65$ With contemporary techniques, occlusal forces are distributed in two directions (compression forces at the cervical butt joint and shear forces along the axial walls), thereby reducing the stresses acting directly on the pulpal floor. ${ }^{66}$ Moreover, strict adherence to the adhesive protocol results in stronger marginal sealing, which prevents microbial penetration at the tooth-restoration interface. ${ }^{67 ; 68}$

These developments in the field of dentistry indicate that traditional principles for the restoration of endodontically treated teeth, especially those with minimal tissue loss, require revision. Attention should be focused on the benefit of the post itself rather than the type of post used, ${ }^{69}$ because the original purpose of the post is to retain the core ${ }^{70}$ rather than to increase the intrinsic resistance of the root $^{71}$ or the fatigue resistance of posterior teeth. ${ }^{72}$ 


\section{Selection of restorative material}

Numerous studies have compared restoration materials in terms of biomechanical behavior and performance. Today's dentists have a wide range of materials to select from, and they must thoroughly understand and consider the unique biomechanical behavior of each in order to make a well-informed decision. In selecting materials, dentists seek to maximize the longevity of the restoration as well as the endodontically treated teeth. Improvements to the computer-aided design / computer-aided manufacturing (CAD/CAM) system have allowed for highly precise marginal adaptation with reduced operating time is easily. ${ }^{73} 74$ In comparison to conventional fabrication techniques, contemporary restorations are manufactured economically and without errors, as laboratory and clinical manufacturing processes have been streamlined. ${ }^{74 ; 75}$ Fabrication of the restoration chairside through the use of CAD/CAM obviates the need for a temporary restoration. Stronger seals on endodontically treated teeth prevent marginal leakage, which previously plagued weak interim restorations. ${ }^{76 ; 77}$

Along with the improvements in CAD/CAM, new and varied restorative materials with improved mechanical and aesthetic properties are continually being developed..$^{78}$

Leucite-reinforced ceramics with enhanced flexibility and 400-MPa fracture resistance were developed to provide a more aesthetic outcome than that achieved with feldspathic ceramics or lithium disilicate-reinforced ceramics. The use of monolithic zirconia was introduced to prevent chipping, which was common when veneering ceramic was used for early generation zirconia ceramics. In addition to improved ceramic materials, composite-based materials with elastic moduli similar to those of dentin have been developed. Materials such as resinceramic and polymer-infiltrated ceramic improve the absorbance of stress. ${ }^{79 ; 80}$

The endocrown is a conservative restorative option for endodontically treated teeth in which one half of the coronal structure is missing and for teeth with short clinical crowns and/or slender or calcified root canals. ${ }^{64 ; 72 ; 81}$ Moreover, endocrown restorations can be used to rehabilitate teeth without adequate ferrule effect and/or insufficient interocclusal space for both core and crown material. ${ }^{61}$ This concept was first proposed in 1995 by Pissis ${ }^{82}$ who advocated for use of the pulp chamber as a monoblock of heat-pressed ceramic to improve macromechanical retention. In 1999, Bindl and Moramann first used the term "endocrown" to refer to an all-ceramic restoration with improved macromechanical as well as micromechanical retention from the pulp chamber and adhesive cementation to the tooth. ${ }^{76 ; 83}$

In addition to the conservation of healthy tooth tissue, endocrowns also save time by decreasing the number of clinical and laboratory steps necessary, compared with conventional crown restoration. ${ }^{61}$ Use of a monoblock has been reported to decrease the stresses that accumulate at the interface of materials with different elastic moduli. ${ }^{84 ; 85}$

In the literature, higher fracture strength values were reported for endocrowns $(674.75 \mathrm{~N})$, compared to conventional crowns on fiber postcomposite cores $(469.90 \mathrm{~N}) .^{72}$ In another study on premolars, leucite glass-ceramic endocrown restorations showed statistically higher fracture resistance $(1,446.68 \mathrm{~N})$ than all-ceramic crowns on fiber post-composite cores $(1,163.30 \mathrm{~N})$. These results were attributed to the increased thickness of the ceramic materials used in endocrowns and the reduced number of interfacial surfaces with use of a monoblock rather than post-core crowns. ${ }^{72 ; 86}$

Minimally invasive preparations, which maximize tissue preservation, are now considered the gold standard for restoring endodontically treated teeth. The insertion of intraradicular posts has become the exception rather than the rule. ${ }^{87}$

Van Dijken et al. ${ }^{88 ; 89}$ found that the high rate of success achieved with the use of dentin enamelbonded ceramic coverage reduces the need for 
traditional full-coverage therapy and/or placements of a post or pin(s) and core. Other laboratory studies have shown that fracture resistance was similar in teeth restored with endocrowns and in teeth with full crowns and fiber post-composite cores..$^{90 ; 91 ; 92 ; 93 ; 94}$ One meta-analysis found that endocrowns perform similarly or better than conventional treatment with intraradicular posts, direct composite resin, and inlay/onlay restoration. The clinical success rate of endocrowns over a 36-months period varies from $94 \%-100 \% ;{ }^{95}$ the 10 -year survival rate is $98.8 \% .{ }^{96}$ Otto et al. ${ }^{97}$ reported the survival rate of endocrowns in molars and premolars over a 12-year follow-up period as $90.5 \%$ and $75 \%$, respectively.

The fracture strength of ceramic materials in endocrown restorations was also evaluated in other studies. The highest fracture strength was reported in the resin-ceramic group (Lava Ultimate) $(1,583.28$ $\mathrm{N}$ ), whereas there was no statistically significant difference between feldspathic (Cerec blocks) $(1,340.92 \mathrm{~N})$ and lithium disilicate-reinforced glassceramic (IPS e.max CAD) $(1,368.77 \mathrm{~N}){ }^{61}$

Through improved physical, mechanical and aesthetic properties, fiber-reinforced composite systems have made the transition from intracoronal restorations to crown and bridge restorations. Fiberreinforced composite systems have elastic moduli similar to that of dentin, with decreased crack propagation and higher fracture resistance than ceramics. ${ }^{98-102}$ However, resin composite materials appear to have increased risk for microleakage over time. ${ }^{61}$ Resin composite materials are also weaker than lithium disilicate glass-ceramics under nonaxial loading conditions. ${ }^{103}$

\section{Immediate dentin sealing}

The immediate dentin sealing protocol has been proposed as an effective technique for sealing the dentinal tubules during the provisionalization phase, decreasing bacterial contamination, and improving bond strength in the final restoration. ${ }^{12}$
Traditionally, delayed dentine sealing is performed with indirect restorations at the final cementation stage. However, delayed dentine sealing results in inferior bond strength, compared to immediate dentin sealing. With the latter technique, bonding is achieved with freshly cut dentin, which is present only at the time of tooth preparation and before impression making. ${ }^{104-106}$

Magne et al. ${ }^{13}$ strongly recommend immediate dentin sealing with either total-etch or self-etch dentin-bonding agents, which they claim improves bond strength in indirect restorations. Several studies have demonstrated that immediate dentin sealing results in better long-term bonding to dentin, compared to that achieved with resin cement alone in the context of delayed dentin sealing. ${ }^{13 ;}$ 106; 107; 108; 109; 110; 111 One study compared mean microtensile bond strength with use of a 3-step etch-and-rinse dentin bonding agent for immediate dentin sealing, compared with delayed dentin bonding. Microtensile bond strength was 5 times higher in the immediate dentin sealing group, compared with the delayed dentin bonding group. ${ }^{13}$

Immediate dentin sealing also prevents collapse of the unpolymerized dentine-resin hybrid layer under the pressure created during seating of the indirect restoration. ${ }^{12-114}$ Traditional delayed dentine bonding raises two challenges. First, during insertion of the restoration, the outwardly directed flow of dentinal fluid dilutes the bonding agent and blocks microporosities into which resin otherwise would have penetrated under an immediate dentin sealing protocol. ${ }^{115}$ Second, the pressure of the luting resin used during restoration seating can cause demineralized dentin to collapse, with effects on adhesion. ${ }^{116}$

When using immediate dentin sealing with indirect restorations, delayed restoration placement and delayed exposure to occlusal loading allow the dentin bond to develop and mature without stress. ${ }^{106}$ Magne recommends that immediate dentin sealing be performed in combination with the total-etch 
technique, ${ }^{12}$ which may include use of a three-step (separate primer and resin) or two-step (self-priming resin) dentin-bonding agent. When cementing the definitive restoration, the surface sealed with unfilled adhesive resin should be cleaned gently with a soft brush and pumice only. Then the entire preparation can be etched and bonded, according to the manufacturer's recommendations. ${ }^{12}$

\section{CONCLUSION}

By adopting the concept of minimally invasive dentistry, practitioners can switch approaches in the contexts of endodontic treatment and the restoration of endodontically treated teeth to maximize the preservation and conservation of enamel, dentin, and the dentino-enamel junction. Maintaining the structural integrity of the pericervical area of the tooth (approximately $4 \mathrm{~mm}$ above and below the alveolar crest) is of the utmost importance during cavity access and instrumentation. This is particularly true for the treatment of molars.

We are in a new era in endodontics, with the introduction of improved disinfection systems that do not require changing a non-round canal to a round shape with aggressive canal flaring. Recent researches have focused more on physical means that improve disinfection, such as sonic and ultrasonic techniques, as well as laser activation. The use of bioceramic-based sealers, which are hydrophilic, adhesive, and bond chemically to root canal dentinal walls, appears to be an effective approach to overcome the microspace issue associated with the use of traditional sealers.

Recent clinical research on vital pulp therapy has led to the development of new protocols for the treatment of cases with irreversible pulpitis. By preserving the pulp tissue, physiological and defensive functions are maintained, and less hard tissue is removed, which results in a stronger tooth. ${ }^{45}$

There has recently been a shift towards reducing the amount of tooth structure removed during endodontic treatment. Instead of traditional access design, the location and size of the access cavity are now determined by considering the specifics of a given tooth.

Modifications to access cavity design include the "Ninja" outline, an "X-entry" design, constructed or conservative endodontic access cavities, and the implementation of image-guided access design "truss" access. Dynamically guided access (3D) appears to provide a significant advantage over traditional (2D) guided access cavity procedures. ${ }^{22}$

The immediate dentin sealing protocol has been proposed as an effective technique for sealing the dentinal tubules during the provisionalization phase to prevent or reduce bacterial contamination, as well as to improve bond strength in the final restoration. Ongoing studies have been designed to compare materials in terms of biomechanical behavior and performance. Today's dentists have a wide range of materials to select from, and they have to understand and consider the biomechanical behavior and properties of each to make a wellinformed decision.

\section{REFERENCES}

1 ENDODONTOLOGY, E. S. O. Quality guidelines for endodontic treatment: consensus report of the European Society of Endodontology. Int Endod J, v. 39, n. 12, p. 921 30, Dec 2006. ISSN 0143-2885. Disponível em: < https:// www.ncbi.nlm.nih.gov/pubmed/17180780 >

2 ELIYAS, S.; JALILI, J.; MARTIN, N. Restoration of the root canal treated tooth. Br Dent J, v. 218, n. 2, p. 53-62, Jan 2015. ISSN 1476-5373. Disponível em: < https://www. ncbi.nlm.nih.gov/pubmed/25613259>.

3 GONZÁLEZ-LÓPEZ, S. et al. Effect of restorative procedures and occlusal loading on cuspal deflection. Oper Dent, v. 31, n. 1, p. 33-8, 2006 Jan-Feb 2006. ISSN 03617734. Disponível em: < https://www.ncbi.nlm.nih.gov/ pubmed $/ 16536191>$.

4 TRONSTAD, L. et al. Influence of coronal restorations on the periapical health of endodontically treated teeth. Endod Dent Traumatol, v. 16, n. 5, p. 218-21, Oct 2000. ISSN 0109-2502. Disponível em: < https://www.ncbi.nlm.nih. gov/pubmed/11202885 > 
5 MINDIOLA, M. J. et al. Endodontic treatment in an American Indian population: a 10-year retrospective study. J Endod, v. 32, n. 9, p. 828-32, Sep 2006. ISSN 00992399. Disponível em: < https://www.ncbi.nlm.nih.gov/ pubmed/16934624 >.

6 SCHILDER, H. Cleaning and shaping the root canal. Dent Clin North Am, v. 18, n. 2, p. 269-96, Apr 1974. ISSN 0011-8532. Disponível em: < https://www.ncbi.nlm.nih. gov/pubmed/4522570 >.

7 ASSIF, D. et al. Assessment of the resistance to fracture of endodontically treated molars restored with amalgam. J Prosthet Dent, v. 89, n. 5, p. 462-5, May 2003. ISSN 00223913. Disponível em: < https://www.ncbi.nlm.nih.gov/ pubmed $/ 12806323>$.

8 JOHNSON, J. K.; SCHWARTZ, N. L.; BLACKWELL, R. T. Evaluation and restoration of endodontically treated posterior teeth. J Am Dent Assoc, v. 93, n. 3, p. 597-605, Sep 1976. ISSN 0002-8177. Disponível em: < https:// www.ncbi.nlm.nih.gov/pubmed/783231 >.

9 LINN, J.; MESSER, H. H. Effect of restorative procedures on the strength of endodontically treated molars. J Endod, v. 20, n. 10, p. 479-85, Oct 1994. ISSN 00992399. Disponível em: < https://www.ncbi.nlm.nih.gov/ pubmed/7714419>.

10 BURKE, F. J. From extension for prevention to prevention of extension: (minimal intervention dentistry). Dent Update, v. 30, n. 9, p. 492-8, 500, 502, Nov 2003. ISSN 0305-5000. Disponível em: < https://www.ncbi.nlm.nih. gov/pubmed/14686189>.

11 BROWET, S.; GERDOLLE, D. Precision and security in restorative dentistry: the synergy of isolation and magnification. Int J Esthet Dent, v. 12, n. 2, p. 172-185, 2017 2017. ISSN 2198-591X. Disponível em: < https:// www.ncbi.nlm.nih.gov/pubmed/28653049>.

12 MAGNE, P. Immediate dentin sealing: a fundamental procedure for indirect bonded restorations. J Esthet Restor Dent, v. 17, n. 3, p. 144-54; discussion 155, 2005. ISSN 1496-4155. Disponível em: < https://www.ncbi.nlm.nih. gov/pubmed/15996383 >.

13 MAGNE, P. et al. Immediate dentin sealing improves bond strength of indirect restorations. J Prosthet Dent, v. 94, n. 6, p. 511-9, Dec 2005. ISSN 0022-3913. Disponível em: < https://www.ncbi.nlm.nih.gov/pubmed/16316797 >.

14 NG, Y. L.; MANN, V.; GULABIVALA, K. A prospective study of the factors affecting outcomes of nonsurgical root canal treatment: part 1: periapical health. Int Endod J, v. 44, n. 7, p. 583-609, Jul 2011. ISSN 1365-2591. Disponível em: < https://www.ncbi.nlm.nih.gov/pubmed/21366626>.
$15 \mathrm{Ng}$ Y. L et al A prospective study of the factors affecting outcomes of non-surgical root canal treatment: part 2: tooth survival. Int Endod J, v. 44, n. 7, p. 610-25, Jul 2011. ISSN 1365-2591. Disponível em: < https://www.ncbi.nlm. nih.gov/pubmed/21366627 >.

16 GILLEN, B. M. et al. Impact of the quality of coronal restoration versus the quality of root canal fillings on success of root canal treatment: a systematic review and meta-analysis. J Endod, v. 37, n. 7, p. 895-902, Jul 2011. ISSN 1878-3554. Disponível em: < https://www.ncbi.nlm. nih.gov/pubmed/21689541 >.

17 AL-OMIRI, M. K. et al. Fracture resistance of teeth restored with post-retained restorations: an overview. J Endod, v. 36, n. 9, p. 1439-49, Sep 2010. ISSN 18783554. Disponível em: < https://www.ncbi.nlm.nih.gov/ pubmed/20728706 >.

18 REEH, E. S.; MESSER, H. H.; DOUGLAS, W. H. Reduction in tooth stiffness as a result of endodontic and restorative procedures. J Endod, v. 15, n. 11, p. 512-6, Nov 1989. ISSN 0099-2399. Disponível em: < https://www. ncbi.nlm.nih.gov/pubmed/2639947 >.

19 CLARK, D.; KHADEMI, J. Modern molar endodontic access and directed dentin conservation. Dent Clin North Am, v. 54, n. 2, p. 249-73, Apr 2010. ISSN 15580512. Disponível em: < https://www.ncbi.nlm.nih.gov/ pubmed/20433977>.

20 Clark, D.; Khademi, J.; Herbranson, E. Fracture resistant endodontic and restorative preparations. Dent Today, v. 32, n. 2,p. 118, 120-3, Feb 2013. ISSN 8750-2186. Disponível em: < https://www.ncbi.nlm.nih.gov/pubmed/23431876>.

21 PLOTINO, G. et al. Fracture Strength of Endodontically Treated Teeth with Different Access Cavity Designs. J Endod, v. 43, n. 6, p. 995-1000, Jun 2017. ISSN 18783554. Disponível em: < https://www.ncbi.nlm.nih.gov/ pubmed/28416305 >

22 Stephen Buchanan, L. Dynamic CT-Guided Endodontic Access Procedures. Dental Education Laboratories, 2018.

23 CLARK, D.; KHADEMI, J. A. Case studies in modern molar endodontic access and directed dentin conservation. Dent Clin North Am, v. 54, n. 2, p. 275-89, Apr 2010. ISSN 1558-0512. Disponível em: < https://www.ncbi.nlm.nih. gov/pubmed/20433978 >.

24 LENCHNER, N. H. Considering the "ferrule effect". Pract Proced Aesthet Dent, v. 13, n. 2, p. 102, Mar 2001. ISSN 1534-6846. Disponível em: < https://www.ncbi.nlm.nih. gov/pubmed/11315426 >. 
25 CARR, G. B. Microscopes in endodontics. J Calif Dent Assoc, v. 20, n. 11, p. 55-61, Nov 1992. ISSN 10432256. Disponível em: < https://www.ncbi.nlm.nih.gov/ pubmed/1284396 >

26 BARNETT, F. Best practices in endodontics: A desk reference. Journal of Conservative Dentistry, v. 18, n. 6, p. 507-507, 2015.

27 BRIEF, J. et al. Accuracy of image-guided implantology. Clin Oral Implants Res, v. 16, n. 4, p. 495-501, Aug 2005. ISSN 0905-7161. Disponível em: < https://www.ncbi.nlm. nih.gov/pubmed/16117776 >

28 ANDERSON, J.; WEALLEANS, J.; RAY, J. Endodontic applications of 3D printing. Int Endod J, v. 51, n. 9, p. 1005-1018, Sep 2018. ISSN 1365-2591. Disponível em: < https://www.ncbi.nlm.nih.gov/pubmed/29486052 >.

29 WU, M. K.; DUMMER, P. M.; WESSELINK, P. R. Consequences of and strategies to deal with residual posttreatment root canal infection. Int Endod J, v. 39, n. 5, p. 343-56, May 2006. ISSN 0143-2885. Disponível em: < https://www.ncbi.nlm.nih.gov/pubmed/16640632 >.

30 ERICSON, D. What is minimally invasive dentistry? Oral Health Prev Dent, v. 2 Suppl 1, p. 287-92, 2004. ISSN 1602-1622. Disponível em: < https://www.ncbi.nlm.nih. gov/pubmed/15646587 >.

31 HUANG, T. J.; SCHILDER, H.; NATHANSON, D. Effects of moisture content and endodontic treatment on some mechanical properties of human dentin. J Endod, v. 18, n. 5, p. 209-15, May 1992. ISSN 0099-2399. Disponível em: < https://www.ncbi.nlm.nih.gov/pubmed/1402574 >.

32 SEDGLEY, C. M.; MESSER, H. H. Are endodontically treated teeth more brittle? J Endod, v. 18, n. 7, p. 332-5, Jul 1992. ISSN 0099-2399. Disponível em: < https://www. ncbi.nlm.nih.gov/pubmed/1402595 >.

33 BUCHANAN, L. S. The standardized-taper root canal preparation--Part 1. Concepts for variably tapered shaping instruments. Int Endod J, v. 33, n. 6, p. 516-29, Nov 2000. ISSN 0143-2885. Disponível em: < https://www.ncbi.nlm. nih.gov/pubmed/11307255 >

34 Buchanan L.S. The standardized-taper root canal preparation--Part 2. GT file selection and safe handpiecedriven file use. Int Endod J, v. 34, n. 1, p. 63-71, Jan 2001. ISSN 0143-2885. Disponível em: < https://www.ncbi.nlm. nih.gov/pubmed/11307382 >

35 RUDDLE, C. J. Nickel-titanium rotary instruments: current concepts for preparing the root canal system. Aust Endod J, v. 29, n. 2, p. 87-98, Aug 2003. ISSN 1329-
1947. Disponível em: < https://www.ncbi.nlm.nih.gov/ pubmed/14655822 >

36 YARED, G. M.; DAGHER, F. E. Influence of apical enlargement on bacterial infection during treatment of apical periodontitis. J Endod, v. 20, n. 11, p. 535-7, Nov 1994. ISSN 0099-2399. Disponível em: < https://www. ncbi.nlm.nih.gov/pubmed/7643036 >.

37 ØRSTAVIK, D.; QVIST, V.; STOLTZE, K. A multivariate analysis of the outcome of endodontic treatment. Eur $\mathrm{J}$ Oral Sci, v. 112, n. 3, p. 224-30, Jun 2004. ISSN 09098836. Disponível em: < https://www.ncbi.nlm.nih.gov/ pubmed/15154919>.

38 WALIA, H. M.; BRANTLEY, W. A.; GERSTEIN, H. An initial investigation of the bending and torsional properties of Nitinol root canal files. J Endod, v. 14, n. 7, p. 346-51, Jul 1988. ISSN 0099-2399. Disponível em: < https://www. ncbi.nlm.nih.gov/pubmed/3251996 >.

39 PETERS, O. A. et al. Three-dimensional analysis of root canal geometry by high-resolution computed tomography. J Dent Res, v. 79, n. 6, p. 1405-9, Jun 2000. ISSN 00220345. Disponível em: < https://www.ncbi.nlm.nih.gov/ pubmed/10890720 >

40 KLYN, S. L.; KIRKPATRICK, T. C.; RUTLEDGE, R. E. In vitro comparisons of debris removal of the EndoActivator system, the F file, ultrasonic irrigation, and $\mathrm{NaOCl}$ irrigation alone after hand-rotary instrumentation in human mandibular molars. J Endod, v. 36, n. 8, p. $1367-$ 71, Aug 2010. ISSN 1878-3554. Disponível em: < https:// www.ncbi.nlm.nih.gov/pubmed/20647098 >.

41 PETERS, O. A. et al. Disinfection of root canals with photon-initiated photoacoustic streaming. J Endod, v. 37 , n. 7, p. 1008-12, Jul 2011. ISSN 1878-3554. Disponível em: < https://www.ncbi.nlm.nih.gov/pubmed/21689561 >

42 HAAPASAlO, M. et al. Tissue dissolution by a novel multisonic ultracleaning system and sodium hypochlorite. J Endod, v. 40, n. 8, p. 1178-81, Aug 2014. ISSN 18783554. Disponível em: < https://www.ncbi.nlm.nih.gov/ pubmed/25069928 >

43 MA, J. et al. In vitro study of calcium hydroxide removal from mandibular molar root canals. J Endod, v. 41, n. 4, p. 553-8, Apr 2015. ISSN 1878-3554. Disponível em: < https://www.ncbi.nlm.nih.gov/pubmed/25596727 >.

44 SIGURDSSON, A. et al. Six-month healing success rates after endodontic treatment using the novel GentleWave ${ }^{\mathrm{TM}}$ System: The pure prospective multi-center clinical study. J Clin Exp Dent, v. 8, n. 3, p. e290-8, Jul 2016. ISSN 19895488. Disponível em: < https://www.ncbi.nlm.nih.gov/ pubmed $/ 27398180>$. 
45 AGUILAR, P.; LINSUWANONT, P. Vital pulp therapy in vital permanent teeth with cariously exposed pulp: a systematic review. J Endod, v. 37, n. 5, p. 581-7, May 2011. ISSN 1878-3554. Disponível em: < https://www.ncbi.nlm. nih.gov/pubmed/21496652 >

46 SIMON, S. et al. Should pulp chamber pulpotomy be seen as a permanent treatment? Some preliminary thoughts. Int Endod J, v. 46, n. 1, p. 79-87, Jan 2013. ISSN 13652591. Disponível em: < https://www.ncbi.nlm.nih.gov/ pubmed/22900881 >.

47 TOMSON, P. L. et al. Growth factor release from dentine matrix by pulp-capping agents promotes pulp tissue repairassociated events. Int Endod J, v. 50, n. 3, p. 281-292, Mar 2017. ISSN 1365-2591. Disponível em: < https://www. ncbi.nlm.nih.gov/pubmed/26913698 >.

48 ASGARY, S.; KEMAL ÇALIŞKAN, M. Vital Pulp Therapy of a Mature Molar with Concurrent Hyperplastic Pulpitis, Internal Root Resorption and Periradicular Periodontitis: A Case Report. Iran Endod J, v. 10, n. 4, p. 284-6, 2015. ISSN 1735-7497. Disponível em: < https://www. ncbi.nlm.nih.gov/pubmed/26523145 >.

49 TAHA, N. A.; AHMAD, M. B.; GHANIM, A. Assessment of Mineral Trioxide Aggregate pulpotomy in mature permanent teeth with carious exposures. Int Endod J, v. 50, n. 2, p. 117-125, Feb 2017. ISSN 1365-2591. Disponível em: < https://www.ncbi.nlm.nih.gov/pubmed/26715408 >.

50 BERGENHOLTZ, G.; SPÅNGBERG, L. CONTROVERSIES IN ENDODONTICS. Crit Rev Oral Biol Med, v. 15, n. 2, p. 99-114, Jan 2004. ISSN 1544-1113. Disponível em: < https://www.ncbi.nlm.nih.gov/pubmed/15059945 >.

51 PRATI, C.; GANDOLFI, M. G. Calcium silicate bioactive cements: Biological perspectives and clinical applications. Dent Mater, v. 31, n. 4, p. 351-70, Apr 2015. ISSN 18790097. Disponível em: < https://www.ncbi.nlm.nih.gov/ pubmed/25662204 >.

52 GHONEIM, A. G. et al. Resistance to fracture of roots obturated with novel canal-filling systems. J Endod, v. 37, n. 11, p. 1590-2, Nov 2011. ISSN 1878-3554. Disponível em: < https://www.ncbi.nlm.nih.gov/pubmed/22000470>.

53 ULUSOY, Ö.; NAYIR, Y.; DARENDELILER-YAMAN, S. Effect of different root canal sealers on fracture strength of simulated immature roots. Oral Surg Oral Med Oral Pathol Oral Radiol Endod, v. 112, n. 4, p. 544-7, Oct 2011. ISSN 1528-395X. Disponível em: < https://www.ncbi. nlm.nih.gov/pubmed/21778088 > .

54 TOPÇUOĞLU, H. S. et al. In vitro fracture resistance of roots obturated with epoxy resin-based, mineral trioxide ag- gregate-based, and bioceramic root canal sealers. J Endod, v. 39, n. 12, p. 1630-3, Dec 2013. ISSN 1878-3554. Disponível em: < https://www.ncbi.nlm.nih.gov/pubmed/24238462 >.

55 TROPE, M.; BUNES, A.; DEBELIAN, G. Root filling materials and techniques: bioceramics a new hope? Endod Topics, v. 32, p. 86-96, 2015.

56 KOSSEV, D.; STEFANOV, V. Ceramics-based sealers as new alternative to currently used endodontic sealers. Root, p. 42-48, 2009.

57 OLIVEIRA, F. E. C.; DENEHY, G. E.; BOYER, D. B. Fracture resistance of endodontically prepared teeth using various restorative materials. J Am Dent Assoc, v. 115, n. 1, p. 57-60, Jul 1987. ISSN 0002-8177. Disponível em: < https://www.ncbi.nlm.nih.gov/pubmed/3475370 >.

58 REEH, E. S.; DOUGLAS, W. H.; MESSER, H. H. Stiffness of endodontically-treated teeth related to restoration technique. J Dent Res, v. 68, n. 11, p. 1540-4, Nov 1989. ISSN 0022-0345. Disponível em: < https://www.ncbi.nlm. nih.gov/pubmed/2584522 >.

59 TORABINEJAD, M.; UNG, B.; KETTERING, J. D. In vitro bacterial penetration of coronally unsealed endodontically treated teeth. J Endod, v. 16, n. 12, p. 566-9, Dec 1990. ISSN 0099-2399. Disponível em: < https://www. ncbi.nlm.nih.gov/pubmed/2094758 >.

60 KÖLPIN, M.; STERZENBACH, G.; NAUMANN, M. Composite filling or single crown? The clinical dilemma of how to restore endodontically treated teeth. Quintessence Int, v. 45, n. 6, p. 457-66, Jun 2014. ISSN 19367163. Disponível em: < https://www.ncbi.nlm.nih.gov/ pubmed/24701612>.

61 EL-DAMANHOURY, H. M.; HAJ-ALI, R. N.; PLATT, J. A. Fracture resistance and microleakage of endocrowns utilizing three CAD-CAM blocks. Oper Dent, v. 40, n. 2, p. 201-10, 2015 Mar-Apr 2015. ISSN 1559-2863. Disponível em: < https://www.ncbi.nlm.nih.gov/pubmed/25268039>.

62 FAGES, M.; BENNASAR, B. The endocrown: a different type of all-ceramic reconstruction for molars. J Can Dent Assoc, v. 79, p.d140, 2013. ISSN 0709-8936. Disponível em: < https://www.ncbi.nlm.nih.gov/pubmed/24309044 >.

63 TZIMAS, K. et al. Endocrown restorations for extensively damaged posterior teeth: clinical performance of three cases. Restor Dent Endod, v. 43, n. 4, p. e38, Nov 2018. ISSN 2234-7658. Disponível em: < https://www.ncbi.nlm. nih.gov/pubmed/30483462 >.

64 SEVIMLI, G.; CENGIZ, S.; ORUC, M. S. Endocrowns: review. J Istanb Univ Fac Dent, v. 49, n. 2, p. 57-63, 2015. 
ISSN 2149-2352. Disponível em: < https://www.ncbi.nlm. nih.gov/pubmed/28955538 >.

BERNHART, J. et al. Cerec3D endocrowns--two-year clinical examination of CAD/CAM crowns for restoring endodontically treated molars. Int J Comput Dent, v. 13, n. 2, p. 141-54, 2010. ISSN 1463-4201. Disponível em: < https://www.ncbi.nlm.nih.gov/pubmed/20648740 >.

GILBOE, D. B.; TETERUCK, W. R. Fundamentals of extracoronal tooth preparation. Part I. Retention and resistance form. 1974. J Prosthet Dent, v. 94, n. 2, p. 1057, Aug 2005. ISSN 0022-3913. Disponível em: < https:// www.ncbi.nlm.nih.gov/pubmed/16046962 >.

67 PASHLEY, E. L. et al. Dentin permeability: sealing the dentin in crown preparations. Oper Dent, v. 17, n. 1, p. 1320, 1992 Jan-Feb 1992. ISSN 0361-7734. Disponível em: < https://www.ncbi.nlm.nih.gov/pubmed/1437680>

68 Abo-Elmagd, A. A. A.; Abdel-Aziz, M. Y. Influence Of Marginal Preparation Design On Microleakage And Marginal GAP of Endocrown Cemented With Adhesive Resin Cement. Egyptian Dental Journal, V. 61, P. 5481:5489, 2015.

69 MAGNE, P. et al. Ferrule-Effect Dominates Over Use of a Fiber Post When Restoring Endodontically Treated Incisors: An In Vitro Study. Oper Dent, v. 42, n. 4, p. 396406, 2017 Jul/Aug 2017. ISSN 1559-2863. Disponível em: < https://www.ncbi.nlm.nih.gov/pubmed/28402738>.

70 SCHWARTZ, R. S.; ROBBINS, J. W. Post placement and restoration of endodontically treated teeth: a literature review. J Endod, v. 30, n. 5, p. 289-301, May 2004. ISSN 0099-2399. Disponível em: < https://www.ncbi.nlm.nih. gov/pubmed/15107639>.

71 RASIMICK, B. J. et al. A review of failure modes in teeth restored with adhesively luted endodontic dowels. J Prosthodont, v. 19, n. 8, p. 639-46, Dec 2010. ISSN 1532849X. Disponível em: < https://www.ncbi.nlm.nih.gov/ pubmed $/ 21040098>$.

72 BIACCHI, G. R.; BASTING, R. T. Comparison of fracture strength of endocrowns and glass fiber post-retained conventional crowns. Oper Dent, v. 37, n. 2, p. 130-6, 2012 Mar-Apr 2012. ISSN 0361-7734. Disponível em: < https:// www.ncbi.nlm.nih.gov/pubmed/21942234 >.

73 MÖRMANN, W. H.; BINDL, A. All-ceramic, chairside computer-aided design/computer-aided machining restorations. Dent Clin North Am, v. 46, n. 2, p. 405-26, viii, Apr 2002. ISSN 0011-8532. Disponível em: < https:// www.ncbi.nlm.nih.gov/pubmed/12014040 >.
74 MEHL, A.; HICKEL, R. Current state of development and perspectives of machine-based production methods for dental restorations. Int J Comput Dent, v. 2, n. 1, p. 9-35, Jan 1999. ISSN 1463-4201. Disponível em: < https://www. ncbi.nlm.nih.gov/pubmed/11351454 >.

75 KANAT, B. et al. Effect of various veneering techniques on mechanical strength of computer-controlled zirconia framework designs. J Prosthodont, v. 23, n. 6, p. 445-55, Aug 2014. ISSN 1532-849X. Disponível em: < https:// www.ncbi.nlm.nih.gov/pubmed/24417370 > .

76 BINDL, A.; MÖRMANN, W. H. Clinical evaluation of adhesively placed Cerec endo-crowns after 2 years-preliminary results. J Adhes Dent, v. 1, n. 3, p. 255-65, 1999. ISSN 1461-5185. Disponível em: < https://www. ncbi.nlm.nih.gov/pubmed/11725673 >.

77 AKTAS, G.; YERLIKAYA, H.; AKCA, K. Mechanical Failure of Endocrowns Manufactured with Different Ceramic Materials: An In Vitro Biomechanical Study. J Prosthodont, v. 27, n. 4, p. 340-346, Apr 2018. ISSN 1532849X. Disponível em: < https://www.ncbi.nlm.nih.gov/ pubmed $/ 27465810>$.

78 BINDL, A.; LÜTHY, H.; MÖRMANN, W. H. Strength and fracture pattern of monolithic CAD/CAM-generated posterior crowns. Dent Mater, v. 22, n. 1, p. 29-36, Jan 2006. ISSN 0109-5641. Disponível em: < https://www. ncbi.nlm.nih.gov/pubmed/16040113 >.

79 LavaTM Ultimate CAD/CAM Restorative. Technical Product Profile. . http://multimedia.3m.com/mws/media/777230O/ lava-ultimate-cad-cam-restorative-tpp-us.pdf,

80 Vita Enamic.Technical and scientific documentation http:// vitanorthamerica.com/ wp-content/ uploads/2013/ 07/ Enamic-Technical-L-10025E.pdf-8_13.pdf,

81 LANDER, E.; DIETSCHI, D. Endocrowns: a clinical report. Quintessence Int, v. 39, n. 2, p. 99-106, Feb 2008. ISSN 1936-7163. Disponível em: < https://www.ncbi.nlm. nih.gov/pubmed/18560648 >.

82 PISSIS, P. Fabrication of a metal-free ceramic restoration utilizing the monobloc technique. Pract Periodontics Aesthet Dent, v. 7, n. 5, p. 83-94, 1995 Jun-Jul 1995. ISSN 1042-2722. Disponível em: < https://www.ncbi.nlm.nih. gov/pubmed/7548896>.

83 ROCCA, G. T.; KREJCI, I. Crown and post-free adhesive restorations for endodontically treated posterior teeth: from direct composite to endocrowns. Eur J Esthet Dent, v. 8, n. 2, p. 156-79, 2013. ISSN 1862-0612. Disponível em: < https://www.ncbi.nlm.nih.gov/pubmed/23712338>. 
84 ZARONE, F. et al. Evaluation of the biomechanical behavior of maxillary central incisors restored by means of endocrowns compared to a natural tooth: a 3D static linear finite elements analysis. Dent Mater, v. 22, n. 11, p. 103544, Nov 2006. ISSN 0109-5641. Disponível em: < https:// www.ncbi.nlm.nih.gov/pubmed/16406084 >.

85 ASSIF, D.; GORFIL, C. Biomechanical considerations in restoring endodontically treated teeth. J Prosthet Dent, v. 71, n. 6, p. 565-7, Jun 1994. ISSN 0022-3913. Disponível em: < https://www.ncbi.nlm.nih.gov/pubmed/8040817 >.

86 CHIA-YU, C. et al. Fracture resistance and failure modes of CEREC endo-crowns and conventional post and coresupported CEREC crowns. Journal of Dental Sciences, v. 4, p. 110-117, 2009.

87 DIETSCHI, D. et al. Biomechanical considerations for the restoration of endodontically treated teeth: a systematic review of the literature, Part II (Evaluation of fatigue behavior, interfaces, and in vivo studies). Quintessence Int, v. 39, n. 2, p. 117-29, Feb 2008. ISSN 1936-7163. Disponível em: < https://www.ncbi.nlm.nih.gov/pubmed/18560650 > .

88 VAN DIJKEN, J. W. et al. Restorations with extensive dentin/enamel-bonded ceramic coverage. A 5-year followup. Eur J Oral Sci, v. 109, n. 4, p. 222-9, Aug 2001. ISSN 0909-8836. Disponível em: < https://www.ncbi.nlm.nih. gov/pubmed/11531067 >.

89 VAN DIJKEN, J. W.; HÖRSTEDT, P. Marginal breakdown of fired ceramic inlays cemented with glass polyalkenoate (ionomer) cement or resin composite. J Dent, v. 22, n. 5, p. 265-72, Oct 1994. ISSN 0300-5712. Disponível em: < https://www.ncbi.nlm.nih.gov/pubmed/7962904 >.

90 ROCCA, G. T. et al. The effect of a fiber reinforced cavity configuration on load bearing capacity and failure mode of endodontically treated molars restored with CAD/CAM resin composite overlay restorations. J Dent, v. 43, n. 9, p. 1106-1115, Sep 2015. ISSN 1879-176X. Disponível em: < https://www.ncbi.nlm.nih.gov/pubmed/26149065 >.

91 SALAMEH, Z. et al. Effect of different onlay systems on fracture resistance and failure pattern of endodontically treated mandibular molars restored with and without glass fiber posts. Am J Dent, v. 23, n. 2, p. 81-6, Apr 2010. ISSN 0894-8275. Disponível em: < https://www.ncbi.nlm.nih. gov/pubmed/20608297 >.

92 CARVALHO, A. O. et al. Influence of Adhesive Core Buildup Designs on the Resistance of Endodontically Treated Molars Restored With Lithium Disilicate CAD/ CAM Crowns. Oper Dent, v. 41, n. 1, p. 76-82, 2016 JanFeb 2016. ISSN 1559-2863. Disponível em: < https:// www.ncbi.nlm.nih.gov/pubmed/26266647 >.
93 SCOTTI, N. et al. Is fracture resistance of endodontically treated mandibular molars restored with indirect onlay composite restorations influenced by fibre post insertion? J Dent, v. 40, n. 10, p. 814-20, Oct 2012. ISSN 1879176X. Disponível em: < https://www.ncbi.nlm.nih.gov/ pubmed/22743344 >.

94 MAGNE, P. et al. Influence of no-ferrule and no-post buildup design on the fatigue resistance of endodontically treated molars restored with resin nanoceramic CAD/ CAM crowns. Oper Dent, v. 39, n. 6, p. 595-602, 2014 Nov-Dec 2014. ISSN 1559-2863. Disponível em: < https:// www.ncbi.nlm.nih.gov/pubmed/25084102 >.

95 SEDREZ-PORTO, J. A. et al. Endocrown restorations: A systematic review and meta-analysis. J Dent, v. 52, p. 8-14, 09 2016. ISSN 1879-176X. Disponível em: < https://www. ncbi.nlm.nih.gov/pubmed/27421989>.

96 BELLEFLAMME, M. M. et al. No post-no core approach to restore severely damaged posterior teeth: An up to 10year retrospective study of documented endocrown cases. J Dent, v. 63, p. 1-7, Aug 2017. ISSN 1879-176X. Disponível em: < https://www.ncbi.nlm.nih.gov/pubmed/28456557>.

97 OTTO, T.; MÖRMANN, W. H. Clinical performance of chairside CAD/CAM feldspathic ceramic posterior shoulder crowns and endocrowns up to 12 years. Int $\mathrm{J}$ Comput Dent, v. 18, n. 2, p. 147-61, 2015. ISSN 14634201. Disponível em: < https://www.ncbi.nlm.nih.gov/ pubmed/26110927 >.

98 GÖHRING, T. N.; GALLO, L.; LÜTHY, H. Effect of water storage, thermocycling, the incorporation and site of placement of glass-fibers on the flexural strength of veneering composite. Dent Mater, v. 21, n. 8, p. 761-72, Aug 2005. ISSN 0109-5641. Disponível em: < https:// www.ncbi.nlm.nih.gov/pubmed/15885765 >.

99 KU, C. W.; PARK, S. W.; YANG, H. S. Comparison of the fracture strengths of metal-ceramic crowns and three ceromer crowns. J Prosthet Dent, v. 88, n. 2, p. 170-5, Aug 2002. ISSN 0022-3913. Disponível em: < https://www. ncbi.nlm.nih.gov/pubmed/12397244 >.

100 RAMÍREZ-SEBASTIÀ, A. et al. Composite vs ceramic computer-aided design/computer-assisted manufacturing crowns in endodontically treated teeth: analysis of marginal adaptation. Oper Dent, v. 38, n. 6, p. 663-73, 2013 Nov-Dec 2013. ISSN 1559-2863. Disponível em: < https://www.ncbi.nlm.nih.gov/pubmed/23570296 > .

$101 \mathrm{CHEN}, \mathrm{C}$. et al. The fracture resistance of a CAD/ CAM Resin Nano Ceramic (RNC) and a CAD ceramic at different thicknesses. Dent Mater, v. 30, n. 9, p. 95462, Sep 2014. ISSN 1879-0097. Disponível em: < https:// www.ncbi.nlm.nih.gov/pubmed/25037897 >. 
102 AWADA,A.; NATHANSON, D. Mechanical properties of resin-ceramic CAD/CAM restorative materials. J Prosthet Dent, v. 114, n. 4, p. 587-93, Oct 2015. ISSN 1097-6841. Disponível em: < https://www.ncbi.nlm.nih.gov/pubmed/26141648 >.

103 GRESNIGT, M. M. et al. Fracture strength, failure type and Weibull characteristics of lithium disilicate and multiphase resin composite endocrowns under axial and lateral forces. Dent Mater, v. 32, n. 5, p. 607-14, May 2016. ISSN 1879-0097. Disponível em: < https://www.ncbi.nlm.nih. gov/pubmed/26935018>.

104 PAUL, S. J.; SCHÄRER, P. The dual bonding technique: a modified method to improve adhesive luting procedures. Int J Periodontics Restorative Dent, v. 17, n. 6, p. 536-45, Dec 1997. ISSN 0198-7569. Disponível em: < https:// www.ncbi.nlm.nih.gov/pubmed/9497740 > .

105 BERTSCHINGER, C. et al. Dual application of dentin bonding agents: effect on bond strength. Am J Dent, v. 9, n. 3, p. 115-9, Jun 1996. ISSN 0894-8275. Disponível em: < https://www.ncbi.nlm.nih.gov/pubmed/9002801 >.

106 DIETSCHI, D. et al. Marginal and internal adaptation of class II restorations after immediate or delayed composite placement. J Dent, v. 30, n. 5-6, p. 259-69, 2002 Jul-Aug 2002. ISSN 0300-5712. Disponível em: < https://www. ncbi.nlm.nih.gov/pubmed/12450717 > .

107 DUARTE, S. et al. The effect of immediate dentin sealing on the marginal adaptation and bond strengths of total-etch and self-etch adhesives. J Prosthet Dent, v. 102, n. 1, p. 1-9, Jul 2009. ISSN 1097-6841. Disponível em: < https:// www.ncbi.nlm.nih.gov/pubmed/19573687 >

108 SAHIN, C. et al. In vitro permeability of etch-and-rinse and self-etch adhesives used for immediate dentin sealing. Dent Mater J, v. 31, n. 3, p. 401-8, 2012. ISSN 18811361. Disponível em: < https://www.ncbi.nlm.nih.gov/ pubmed/22673465 >.

109 LEE, J. I.; PARK, S. H. The effect of three variables on shear bond strength when luting a resin inlay to dentin. Oper Dent, v. 34, n. 3, p. 288-92, 2009 May-Jun 2009. ISSN 0361-7734. Disponível em: < https://www.ncbi.nlm. nih.gov/pubmed/19544817 >.
110 DIETSCHI, D.; MAGNE, P.; HOLZ, J. An in vitro study of parameters related to marginal and internal seal of bonded restorations. Quintessence Int, v. 24, n. 4, p. 281-91, Apr 1993. ISSN 0033-6572. Disponível em: < https://www. ncbi.nlm.nih.gov/pubmed/8362041>.

111 SAILER, I. et al. The effects of desensitizing resin, resin sealing, and provisional cement on the bond strength of dentin luted with self-adhesive and conventional resincements. J Prosthet Dent, v. 107, n. 4, p. 252-60, Apr 2012. ISSN 1097-6841. Disponível em: < https://www.ncbi.nlm. nih.gov/pubmed/22475468 >.

112 MAGNE, P.; DOUGLAS, W. H. Porcelain veneers: dentin bonding optimization and biomimetic recovery of the crown. Int J Prosthodont, v. 12, n. 2, p. 111-21, 1999 MarApr 1999. ISSN 0893-2174. Disponível em: < https:// www.ncbi.nlm.nih.gov/pubmed/10371912 >.

113 DIETSCHI, D.; HERZFELD, D. In vitro evaluation of marginal and internal adaptation of class II resin composite restorations after thermal and occlusal stressing. Eur J Oral Sci, v. 106, n. 6, p. 1033-42, Dec 1998. ISSN 09098836. Disponível em: < https://www.ncbi.nlm.nih.gov/ pubmed/9879916>.

114 DIETSCHI, D.; MAGNE, P.; HOLZ, J. Bonded to tooth ceramic restorations: in vitro evaluation of the efficiency and failure mode of two modern adhesives. Schweiz Monatsschr Zahnmed, v. 105, n. 3, p. 299-305, 1995. ISSN 0256-2855. Disponível em: < https://www.ncbi.nlm. nih.gov/pubmed/7716461 >

115 PAUL, S. J.; SCHARER, P. Factors in dentin bonding. Part II: A review of the morphology and physiology of human dentin. J Esthet Dent, v. 5, n. 2, p. 51-4, 1993 Mar-Apr 1993. ISSN 1040-1466. Disponível em: < https://www. ncbi.nlm.nih.gov/pubmed/8240846>.

116 Paul SJ1, Scharer P. Intrapulpal pressure and thermal cycling: effect on shear bond strength of eleven modern dentin bonding agents. J Esthet Dent, v. 5, n. 4, p. 179-85, 1993 Jul-Aug 1993. ISSN 1040-1466. Disponível em: < https://www.ncbi.nlm.nih.gov/pubmed/8037966 >. 